\title{
Role mateřských států v systému meziválečné ochrany národnostních menšin
}

\author{
Harald Christian Scheu
}

Právnická fakulta, Univerzita Karlova

Kontaktni e-mail: scheu@prf.cuni.cz

The Role of Kin States in the System of Interwar Protection of National Minorities

\begin{abstract}
:
The article deals with the system of the League of Nations for the protection of national minorities. We present the material basis of protection which can be found in various minority treaties, minority declarations and peace treaties concluded after the First World War. Particular emphasis is placed on the functioning of the relevant control mechanisms, particularly from the point of view of kin states that support the interests of kin minorities abroad. The analysis shows that the system of the League of Nations for the protection of national minorities was a very interesting experiment which introduced new elements and a new dimension into public international law.
\end{abstract}

\section{Keywords:}

League of Nations; minority protection; kin state; petition; Permanent Court of International Justice

\section{Klíčová slova:}

Společnost národů; ochrana menšin; mateřský stát; petice; Stálý dvůr mezinárodní spravedlnosti

DOI: $10.14712 / 2464689 X .2018 .42$ 
Po skončení první světové války prosadily Čelné mocnosti spojené i sdružené nové geopolitické uspořádání pro Evropu. Na základě Pařížských předměstských smluv došlo k rozsáhlému překreslení státních hranic v Evropě. Vedle vzniku pěti nově nezávislých evropských států a úpravy reparace ze strany poražených států bylo klíčovou součástí smluvního díla založení Společnosti národů jako první mezinárodní organizace politické povahy. ${ }^{1}$ Do agendy této nové organizace byla zařazena mimo jiné i problematika ochrany národnostních menšin. ${ }^{2}$

Vytvoření komplexního systému Společnosti národů na ochranu národnostních menšin představuje mimořádně zajímavý pokus o řešení lidskoprávních otázek v širším kontextu mezinárodního míru. Pablo de Azcarate y Florez, který v letech 1933 až 1936 zastával funkci zástupce generálního tajemníka Společnosti národů, zpětně označil tento systém za experiment. ${ }^{3}$ Také řada autorů dodnes vyzdvihuje unikátní a experimentální charakter ochrany národnostních menšin pod egidou Společnosti národů. ${ }^{4}$

$\mathrm{V}$ tomto příspěvku se chceme věnovat základním prvkům systému ochrany národnostních menšin v meziválečném období. Zvláštní pozornost bude věnována otázce, jakým způsobem mateřské státy využivaly různých mechanismů Společnosti národů k prosazování ochrany svých př́ibuzných menšin v zahraničí.

\section{Právní rámec fungování systému Společnosti národů}

Mezinárodní organizace představují jeden z nejvýznamnějších prvků soudobého mezinárodního práva. Společnost národů jistě nebyla první mezinárodní organizací. Vedle řady mezinárodních konferencí a kongresů, na kterých zástupci suverénních států poměrně volným způsobem řešili otázky války a míru, mezinárodní spolupráce a vzájemného vymezování sfér vlivu, vznikly již v průběhu 19. století některé mezinárodní organizace zaměřené především na technické otázky jako např. Ústřední komise pro plavbu na Rýně v roce 1815, Evropská dunajská komise v roce 1856, Mezinárodní telegrafní unie v roce 1865 a Světová poštovní unie v roce $1874 .{ }^{5}$ V době svého založení a působení Společnost národů ovšem vynikala $\mathrm{z}$ řad jiných mezinárodních organizací svým širokým mandátem a svou universalistickou koncepcí.

Základem prvního mechanismu kolektivní bezpečnosti se měl stát čl. 11 Paktu o Společnosti národů z roku $1919,{ }^{6}$ podle něhož se každá válka nebo hrozba válkou dotýkala zájmů celé Společnosti národů a bylo povinností organizace učinit vhodná opatření, aby

1 K historickým souvislostem vzniku Společnosti národů viz KUKLÍK, J. - PETRÁŠ, R. Nadnárodní integrace v Evropě. Luzern - Praha: Havlíček Brain Team, 2007.

2 Podrobně FINK, C. The Paris Peace Conference and the Question of Minority Rights. Peace \& Change, 1996, roč. 21, č. 3, s. 276-279.

3 DE AZCARATE, P. League of Nations and National Minorities - An Experiment. Washington: Carnegie Endowment for International Peace, 1945.

4 HILPOLD, P. The League of Nations and the protection of minorities - Rediscovering a great experiment. In: VON BOGDANDY, A. - PETERS, A. - WOLFRUM, R. (eds.). Max Planck Yearbook of United Nations Law. Dordrecht, 2013, s. 87-124 (s mnoha dalšími odkazy).

5 Zařazení těchto organizačních struktur do koncepce tradičního mezinárodního práva, podle níž pouze suverénní stát mohl být považován za subjekt mezinárodního práva, bylo problematické. Srov. např. historické pojednání Franze v. Liszta o společných orgánech států. LISZT, F. Das Völkerrecht - systematisch dargestellt. 8. vydání. Berlin: Verlag O. Häring, 1912, s. 135-145.

6 Pakt o Společnosti národů byl podepsán dne 28. dubna 1919 a vstoupil v platnost 10. ledna 1920. 
byl mír mezi národy účinně uchráněn. Podle čl. 2 Paktu o Společnosti národů působily v rámci organizace tři hlavní orgány, a to Shromáždění, Rada a Stálý sekretariát. Zatímco ve Shromáždění měly všechny členské státy rovné zastoupení, Rada byla jako výkonný orgán složena ze sedmi stálých členů a dalších nestálých členů volených na tříleté období. ${ }^{7}$ V čele Stálého sekretariátu organizace stál generální tajemník.

Vzhledem k tomu, že události první světové války a systematické porušování mezinárodních závazků vyvolaly značnou krizi důvěry ve fungování mezinárodního práva, snažili se zakladatelé Společnosti národů vyhnout př́lišnému právnímu formalismu. Stephen Wertheim, historik působící na univerzitě v Cambridgi, upozornil na to, že původní legalistická koncepce vypracovaná právníky byla nahrazena pragmatismem politiků, kteří pro novou organizaci preferovali politické postupy místo judiciálního řešení sporů. Podle Wertheima zakladatelé Společnosti národů spojili do jednoho celku ideje neohegelovského idealismu a protistátního liberalismu. Vzhledem k tomu, že jako významný protagonista Pařížské mírové konference vystupoval americký prezident Woodrow Wilson, není překvapivé, že ideový základ nové organizace byl obohacen také o notnou dávku amerického moralismu. ${ }^{8}$

Nelze popírat, že Společnost národů nabízela různá fóra i právníkům. Mezinárodněprávní aspekty hrály významnou roli např. v mandátním systému Společnosti národů, ${ }^{9}$ a internacionalisté původně také velmi optimisticky přistupovali k otázce kodifikace mezinárodního práva v rámci Společnosti národů. ${ }^{10}$ Nicméně vysoké ambice právníků, kteří si přáli politiku nahradit mezinárodním právem, nevyšly. Nepotvrdila se teze, že pod tlakem veřejného mínění dojde ke zmírnění politických konfliktů a k nárůstu poptávky po používání judiciálních nástrojů řešení mezinárodních sporů. Podle Stephena Wertheima mezinárodněprávní pozitivismus implodoval pod dojmem zkušeností z první světové války. Právní závazky podle zakládacího Paktu o Společnosti národů a navazujících mezinárodních smluv byly proto koncipovány ve velmi vágních formulacích poskytujících státům široký prostor výkladu.

\section{Hlavní prvky meziválečného systému ochrany národnostních menšin}

V tomto kontextu byla koncipována i meziválečná ochrana národnostních menšin. Systém Společnosti národů byl postaven na bilaterálních smlouvách mezi vítěznými mocnostmi první světové války, tzv. Čelnými mocnostmi spojenými i sdruženými, ${ }^{11}$ na jedné straně, a konkrétními národními státy na straně druhé. Podle vzoru menšinové smlouvy s Polskem, která byla podepsána 29. června 1919, vznikly po obsahové stránce z velké

7 Podle čl. 4 Paktu o Společnosti národů se měla Rada skládat ze zástupců Čelných mocností spojených i sdružených (USA, Velká Británie, Francie, Itálie a Japonsko) a ze zástupců čtyř dalších členů organizace. Itálie a Japonsko vystoupily ze Společnosti národů v letech 1937, resp. 1933. Po svém přijetí byly v Radě zastoupeny také Německo (od 1926 do 1933) a Sovětský svaz (od 1934 do 1939). Vzhledem k tomu, že USA do Společnosti národů nikdy nevstoupily, nemohly ani zaujmout své předpokládané místo v Radě.

8 WERTHEIM, S. The League of Nations: A Retreat from International Law? Journal of Global History, 2012, roč. 7, č. 2, s. 210-232.

9 Podrobněji MATZ, N. Civilization and the Mandate System under the League of Nations as Origin of Trusteeship. In: VON BOGDANDY, A. - WOLFRUM, R. (eds.). Max Planck Yearbook of United Nations Law. Dordrecht, 2005, s. 47-95.

10 ROSENNE, S. Codification Revisited after 50 Years. In: FROWEIN, J. - WOLFRUM, R. (eds.). Max Planck Yearbook of United Nations Law. Kluwer Law International, 1998, s. 1-22.

11 Vzhledem k tomu, že USA menšinové smlouvy neratifikovaly, nestaly se smluvní stranou. 
části identické menšinové smlouvy s Jugoslávií (ze dne 10. září 1919), Československem (ze dne 10. záŕí 1919), Rumunskem (ze dne 9. prosince 1919) a Řeckem (ze dne 10. srpna 1920). Podobné závazky obsahovala jednostranná prohlášení o ochraně národnostních menšin, která učinily Albánie (v ř́ijnu 1921), Estonsko (v záŕí 1923), Finsko (v červnu 1921), Lotyšsko (v červnu 1923), Litva (v květnu 1922) a jako jediný příklad mimoevropské země také Irák (v roce 1932). Kromě toho byla ustanovení o ochraně národnostních menšin začleněna do několika mírových smluv (s Rakouskem, Bulharskem, Mad’arskem a Tureckem) či smluv o statusu konkrétních oblastí (Horní Slezsko a Memel).

Co se týče materiálního standardu ochrany národnostních menšin, příslušné dokumenty sdílejí velmi podobnou úpravu. ${ }^{12}$ Významné místo zaujímá zákaz diskriminace. Jako př́íklad lze uvést čl. 2 vzorové menšinové smlouvy s Polskem, který zajišt’uje všem příslušníkům národnostních menšin rovnost v oblastech práva na život, práva na osobní svobodu a svobody náboženského projevu. Podle čl. 7 menšinové smlouvy s Polskem jsou si všichni občané rovni před zákonem a mají stejná občanská a politická práva bez rozlišování na základě rasy, jazyka nebo náboženství.

Další důležitý prvek představuje úprava nabývání státního občanství ze strany příslušníků národnostních menšin. Z čl. 3 vzorové smlouvy s Polskem vyplývá, že občanství nového státu získají všechny osoby, které v rozhodné chvíli (tzn. ve chvíli vstupu menšinové smlouvy v platnost) na území státu pobývají, a to bez ohledu na jejich etnický původ. Pokud si někdo zvolí občanství jiného státu, je povinen se přestěhovat do země svého nového občanství.

Součástí ochrany jsou práva týkající se používání menšinového jazyka zejména v soukromé oblasti, ale částečně také před soudy a v rámci menšinového školství. Podle čl. 9 vzorové smlouvy s Polskem má stát zajistit vhodný rámec pro výuku v menšinovém jazyce. Konkrétní míra veřejné podpory pro výuku v menšinových jazycích záleží na podílu příslušníků národnostních menšin na celkovém obyvatelstvu měst a okresů. Čl. 9 Smlouvy mezi čelnými mocnostmi spojenými i sdruženými a Československem ze dne 10. září 1919 (tzv. Malá Saint-Germainská smlouva) hovoř́i v této souvislosti o městech a okresech, ,v nichž je usedlý značný zlomek československých př́slušníků jiného jazyka než českého“.

Pouze v některých smlouvách byla upravena otázka územní autonomie, např. ve prospěch Zakarpatské Rusi v menšinové smlouvě s Československem ${ }^{13}$ nebo ve prospěch Sedmihradska v menšinové smlouvě s Rumunskem. Ve smlouvách s Polskem, Reckem a Rumunskem byla obsažena zvláštní ustanovení o ochraně práv Židů. Smlouvy s Řeckem a Jugoslávií pamatovaly na postavení muslimů. Podobné ustanovení týkající se rodinného práva muslimů bylo začleněno také do čl. 2 odst. 3 albánského prohlášení z roku 1921.

Co se týče praktické realizace těchto materiálních práv, odkazují menšinové smlouvy na Společnost národů. Podle čl. 12 smlouvy s Polskem měly závazky přijaté ve prospěch národnostních menšin požívat záruky Společnosti národů, přičemž tato záruka zahrnovala tři konkrétní mechanismy. Zaprvé mohl každý člen Rady Společnosti národů upozornit

12 Podrobněji HILPOLD, P. Minderheitenschutz im Völkerbundsystem. In: PAN, C. - PFEIL, B. S. (eds.). Zur Entstehung des modernen Minderheitenschutzes in Europa. Wien: Springer, 2006, s. 156-189.

13 Podle čl. 10 Malé Saint-Germainské smlouvy se Československo zavázalo, že zríidí pro jihokarpatské Rusíny samosprávnou jednotku, která bude vybavena nejširší samosprávou slučitelnou s jednotností státu československého. Čl. 11 a 12 citované smlouvy zmiňují fungování rusínského zákonodárného sněmu a zrrízení funkce guvernéra. 
Radu na každé nastalé či hrozící porušení závazků. Zadruhé mohla Rada v takové věci zvolit vhodné a účinné postupy, resp. vydat pokyny. Zatřetí odkazovaly menšinové smlouvy na čl. 14 Paktu o Společnosti národů, podle něhož o všech sporech mezinárodní povahy mohl rozhodovat Stálý dvůr mezinárodní spravedlnosti. Menšinové smlouvy přitom shodně konstatují, že spory o právních či skutkových otázkách spojených s menšinovými smlouvami je třeba za takové spory mezinárodní povahy považovat. Podnět k přezkumu dané věci mohl vzejít ze strany každého člena Rady Společnosti národů.

Ačkoli menšinové smlouvy neupravovaly podrobný průběh jednotlivých řízení, lze konstatovat, že menšinové smlouvy přinesly v tu dobu nevídaný zásah do suverenity dotčených států. Zatímco politické intervence států ve prospěch prŕibuzných menšin v zahraničí byly zaznamenány i v minulosti, zrrízení systému ochrany národnostních menšin, který byl založen na mezinárodním právu, představoval zcela nový prvek. ${ }^{14}$

Na straně druhé jsou zřejmé i slabiny kontrolního mechanismu, který tkví hlavně v tom, že operace systému je závislá na ochotě jednotlivých států vyvolat mezinárodní spory kvůli zájmům národnostních menšin, jejichž příslušníci nežijí na jejich území a nemají jejich občanství. Praxe ukázala, že za běžných okolností státy nepodávají mezinárodní stížnosti či žaloby proti jiným státům z důvodu porušení lidských práv. Zpravidla nechtějí takovým krokem narušit standardní diplomatické vztahy. ${ }^{15}$ To platí zčásti také pro př́stup mateřských států, které na podporu př́buzných menšin v zahraničí zvolily raději mírnější opatření než podání $\mathrm{k}$ Radě nebo žalobu $\mathrm{k}$ Stálému soudu mezinárodní spravedlnosti. V rámci systému Společnosti národů byl nástroj stížnosti státu v letech 1929 až 1932 využit jen třikrát, a to vždy ze strany Německa jako mateřské země ve prospěch německých menšin v zahraničíi. ${ }^{16}$

Problematická byla ovšem nejen ochota, resp. neochota členů Rady podniknout kroky proti státům porušujícím mezinárodní závazky, ale také způsob rozhodování v samotné Radě. Podle čl. 5 Paktu o Společnosti národů muselo být rozhodnutí Rady přijato se souhlasem všech členů Rady. V politicky citlivých kauzách národnostních menšin byla přitom jednomyslnost v Radě jen stěží dosažitelná. Za určitý nedostatek kontrolního systému lze považovat také skutečnost, že prŕíslušníci národnostních menšin a národnostní menšiny jako př́mo dotčené subjekty neměli podle menšinových smluv možnost vlastním jménem učinit procesní kroky před orgány Společnosti národů a Stálým dvorem mezinárodní spravedlnosti.

\section{Základy fungování petičního řízení}

Vzhledem k výše zmíněným slabinám systému ochrany dospěli zástupci států a Společnosti národů k závěru, že je nutné kontrolní mechanismus vylepšit a zavést jako doplňující prvek petiční řízení, jehož úprava byla postupně modifikována a doplňována. ${ }^{17}$ Základním

14 GARDINER JONES, M. National Minorities: A Case Study in International Protection. Law and Contemporary Problems, 1949, roč. 14, č. 4, s. 599-626, 609.

15 Tento zásadní problém je dobře dokumentován i pro období po druhé světové válce. Ačkoli byl nástroj mezistátní stížnosti po roce 1945 zaveden do řady mezinárodních lidskoprávních úmluv, nebyl na úrovni OSN využit ani jednou, před Evropským soudem pro lidská práva jen velmi zřídka.

16 Podle Hilpolda byly tyto stížnosti v samotné věci úspěšné, ale přesto se z politického hlediska ukázaly jako kontraproduktivní. Srov. HILPOLD, Minderheitenschutz im Völkerbundsystem, s. 172.

17 Podrobněji PRITCHARD, S. Der völkerrechtliche Minderheitenschutz. Historische und neuere Entwicklungen. Berlin: Duncker und Humblot, 2001, s. 85-89. 
kamenem tohoto nástroje se stala zpráva, kterou v roce 1920 předložil Tommaso Tittoni ${ }^{18}$ a která byla Radou Společnosti přijata v ř́jnu 1920. Tittoniho zpráva navazovala na ustanovení menšinových smluv, podle něhož mohl každý člen Rady Společnosti národů upozornit Radu na nastalé či hrozící porušení závazků, a dovodila, že tato úprava nevylučovala, aby př́islušníci národnostních menšin nebo jejich organizace a také státy, které nebyly v Radě zastoupeny, alespoň neformální cestou upozornili Radu na porušení či hrozící porušení závazků podle menšinových smluv. Tittoniho zpráva ovšem připustila, že takový krok př́śslušníků národnostních menšin nemohl znamenat formální zahájení jednání Rady. Mělo se jednat pouze o petici, kterou Rada nebyla povinna se zabývat.

Na základě rozhodnutí Rady ze dne 25. října 1920 byl zřízen mechanismus trríčlenných výborů složených z předsedy Rady a dalších dvou jejích členů. Menšinové výbory po věcné stránce přezkoumaly petice, které jim byly postoupeny, a rozhodly o tom, zda mají být předloženy Radě. Na generálního tajemníka Společnosti národů byla přenesena pravomoc přezkoumat formální přijatelnost petic. Podle rozhodnutí Rady ze dne 5. září 1923 měl generální tajemník konkrétně zjišt'ovat, zda se daná petice dotýkala práva zaručeného menšinovou smlouvou, zda nemírila na přerušení politické vazby mezi národnostní menšinou a územním státem, zda nebyla podána anonymně a zda údajná porušení nebyla již předmětem jiné petice. Při srovnání s podobnými procedurami v rámci současné mezinárodní ochrany lidských práv je pozoruhodné, že v systému Společnosti národů nemuseli autoři petice prokázat, že vyčerpali v dané věci všechny dostupné vnitrostátní opravné prostředky. ${ }^{19}$ Územní stát, proti němuž byla petice namířena, měl dva měsíce na zaslání svého stanoviska. Jak petice, tak i stanovisko státu byly následně předány všem členům Rady. ${ }^{20}$

Po zavedení nového petičního mechanismu zůstalo postavení stěžovatelů poměrně nejasné. Problém spočíval v tom, že se autor petice žádnou formální cestou nedozvěděl o výsledku přezkumu a př́padných krocích Rady. Pouze zřídka byli stěžovatelé ze strany sekretariátů Rady o př́ípadných opatřeních informováni, a to vždy jen neformálně a ústně. ${ }^{21}$ Až v roce 1929 zakotvila Rada Společnosti národů právo stěžovatelů na informaci o přijatelnosti, resp. nepřijatelnosti jejich podání. Stejná rezoluce Rady ze dne 13. června 1929 také stanovila povinnost generálního tajemníka Společnosti národů jednou ročně informovat členy Rady o veškeré komunikaci tříčlenných výborů s Radou. Veřejnost se měla ze strany generálního tajemníka dozvědět o počtech přijatelných a nepřijatelných petic. Samotné závěry šetření tř́členných výborů však mohly být zveřejněny pouze se souhlasem státu, proti němuž bylo šetření vedeno. ${ }^{22}$

Od doby založení petičního řízení v roce 1920 až do reformy v roce 1929 bylo zaznamenáno celkem 149 přijatelných a 306 nepřijatelných petic. ${ }^{23} \mathrm{~V}$ období od roku 1929 do roku

18 V roce 1919 vedl Tommaso Tittoni jako ministr zahraničních věcí italskou delegaci na Pařížské mírové konferenci.

19 HILPOLD, P. The League of Nations and the protection of minorities - Rediscovering a great experiment. In: VON BOGDANDY, A. - PETERS, A. - WOLFRUM, R. (eds.). Max Planck Yearbook of United Nations Law. Dordrecht, 2013, s. 87-124.

20 Do roku 1923 měly být informace o př́ípadu zpř́istupněny všem členům Shromáždění Společnosti národů.

21 SCHEUERMANN, M. Minderheitenschutz contra Konfliktverhütung? Die Minderheitenpolitik des Völkerbundes in den zwanziger Jahren. Marburg: Herder Institut, 2000, s. 36.

22 Podrobně ke genezi a obsahu rezoluce viz GÜTERMANN, C. Das Minderheitenschutzverfahren des Völkerbundes. Berlin: Duncker \& Humblot, 1979, s. 84-117.

23 SCHEUERMANN, c. d., s. 410-412. 
1939 bylo podáno celkem 521 petic, z nichž 225 bylo hodnoceno jako nepřijatelných. ${ }^{24}$ Ve srovnání se podobnými stížnostními mechanismy v rámci současné ochrany lidských práv je poměr přijatelných stížností velmi vysoký. Tato skutečnost zřejmě souvisí s tím, že podstatná část stížností k lidskoprávním orgánům OSN a Evropskému soudu pro lidská práva nesplňuje kritérium vyčerpání vnitrostátních právních prostředků, které ze strany orgánů Společnosti národů nebylo zkoumáno. ${ }^{25}$

Jen velmi málo petic, které byly menšinovými výbory věcně projednány, byly následně postoupeny Radě. Je třeba dodat, že samotné menšinové smlouvy s postoupením petic Radě vủbec nepočítaly, ale v praxi byla tato možnost zavedena. Menšinové výbory ale vycházely z toho, že v rámci diplomatického a důvěrného jednání s dotčeným územním státem lze jednodušeji dosáhnout uspokojivého řešení, než pod tlakem medializace a politizace problému v Radě.

Z přibližně 900 petic, které bylo podáno v letech 1920 až 1940, bylo cca 500 prohlášeno za přijatelné a předáno menšinovým výborům. Radě bylo ovšem předloženo jen 16 z nich. ${ }^{26}$ Přijetí závazných opatření vyžadující jednomyslnost mezi členy Rady bylo v politicky napjaté atmosféře neprríliš reálnou variantou. Hlavní přínos mohl spočívat v samotné diskusi na úrovni Rady a určitém morálním nátlaku na dotčený územní stát.

Ve své směrodatné studii z roku 1979 upozornil Christoph Gütermann na rozdíl mezi formálním a neformálním řízením před tř́ičlenným výborem (procedure écrite, resp. procedure non écrite). ${ }^{27} \mathrm{~V}$ praxi se petiční řízení totiž někdy významně odchýlilo od procesních pravidel. To se týká např. předávání citlivých informací o řízení jednotlivým autorům petic. Ačkoli formální řízení bylo postaveno na zásadě striktní důvěrnosti, jsou známé př́ipady, ve kterých zástupci členských států Společnosti národů intenzivně komunikovali $\mathrm{s}$ autory petic o předběžných výsledcích řízení. Proto mad'arský zástupce u Společnosti národů Zoltan Baranyai v roce 1924 výslovně varoval svoji vládu, aby autoři petic v další komunikaci se Společností národů neprozrazovali, že takovými informacemi disponují a že jim byly postoupeny mad'arskou vládou. ${ }^{28}$ Jsou ovšem známé také prrípady, ve kterých do procesu neformálního jednání s autory petic takto vstupovali i samotní zástupci Společnosti národů, někdy i na podnět př́slušného menšinového výboru.

Je zřejmé, že v této souvislosti hrála součinnost mateřské země se svojí příbuznou menšinou v zahraničí důležitou roli. Podle Zaffiho mohla mít podpora ze strany mateřské země formu pomoci při správném sepisování petic, ale také formu logistické pomoci např. při předání petic do Ženevy a jejich rozmnožování. V některých př́ípadech mateřský stát př́mo koordinoval obsah jednotlivých petic. ${ }^{29}$

24 GARDINER JONES, $c$. d., s. 614.

25 Kevin Boyle uvádí, že 90 \% všech stížností k Evropskému soudu pro lidská práva je odmítnuto jako nepřijatelných, a to nejčastěji z důvodu nevyčerpání vnitrostátních opravných prostředků. Viz BOYLE, K. The European Experience: The European Convention on Human Rights. Victoria University of. Wellington Law Review, 2009, roč. 40, č. 1, s. 165-174.

26 ZAFFI, D. Die Minderheitenpetition im Rahmen der Politik des Völkerbundes. In: CORSINI, U. ZAFFI, D. (eds.). Die Minderheiten zwischen den beiden Weltkriegen. Berlin: Duncker\&Humblot, 1997, s. 197-220. Ke statistice viz také HILPOLD, Minderheitenschutz im Völkerbundsystem, s. 195.

27 GÜTERMANN, c. d., s. 35.

28 ZAFFI, c. d., s. 207-208.

29 ZAFFI, c. d., s. 208. 


\section{Př́nos judikatury Stálého dvora mezinárodní spravedlnosti}

Vedle jednání Rady Společnosti národů a př́nosu petičního řízení před menšinovými výbory je třeba zmínit také význam Stálého dvora mezinárodní spravedlnosti pro meziválečnou ochranu národnostních menšin. V odborné literatuře panuje shoda, že potenciál Stálého dvora byl vcelku jen málo využit. ${ }^{30} \mathrm{Za}$ celou dobu fungování systému Společnosti národů vydal Stálý dvůr jen jeden rozsudek na základě žaloby státu, přičemž se jednalo o žalobu Německa proti Polsku. Další dvě žaloby proti Polsku byly ze strany nacistického Německa staženy. Celkem pětkrát se na Stálý dvůr obrátila Rada Společnosti národů se žádostí o vydání právně nezávazného posudku. I zde převažovaly otázky týkající se ochrany německé menšiny v Polsku (celkem 3 žádosti). Ostatní dva př́ípady se týkaly postavení polské menšiny v Gdaňsku a řecké menšiny v Albánii. Ačkoli počet rozsudků a posudků Stálého dvora není vysoký, přispěla tato judikatura výrazně $\mathrm{k}$ dalšímu vývoji mezinárodněprávní ochrany národnostních menšin. Stálý dvůr se zabýval např. otázkou definice pojmu národnostní menšiny a problémem vymezení principu rovnosti a zákazu diskriminace $\mathrm{z}$ důvodu př́slušnosti $\mathrm{k}$ národnostní menšině. ${ }^{31}$

Co se týče samotného průběhu ř́zení před Soudem, byla role mateřských států důležitá. Poté, co zástupci řeckých pravoslavných organizací poslali do Ženevy řadu petic týkajících se snah albánských orgánů o sekularizaci vzdělávacího systému a marginalizaci řecké menšiny, rozhodla se Rada předložit Stálému dvoru žádost o posudek. Podle Rady měl Stálý dvůr přezkoumat slučitelnost albánských opatření se zásadou rovnosti zajištěnou platnými mezinárodními závazky. ${ }^{32}$ Podle procesních pravidel nemohli autoři petic jako soukromé osoby v řízení před Stálým dvorem vystupovat. Argumenty v jejich prospěch však velmi angažovaně a nakonec také úspěšně hájila řecká vláda. ${ }^{33}$

Obdobně také Německo v řízení př̀ed Stálým dvorem podporovalo zájmy své př́ibuzné menšiny v Polsku. Zatímco během předchozího petičního řízení před př́ilušným menšinovým výborem vycházela formální iniciativa ze strany německé menšinové organizace, v soudním řízení vystupovala $\mathrm{v}$ její prospěch německá vláda. Polsko jako mateřská země podporovalo postavení polské menšiny pobývající na území města Gdaňsk v dalším řízení před Stálým dvorem..$^{34}$ Podle polské vlády porušovalo Svobodné město Gdaňsk zákaz diskriminace stanovený ve Versailleské smlouvě a uvedlo mimo jiné př́íklady týkající se školství, uznávání školských diplomů a uživání polského jazyka. ${ }^{35}$

V červenci 1933 Německo jako mateřská země německé menšiny podalo žalobu proti Polsku v souvislosti s realizací polské pozemkové reformy. Také v tomto př́ípadě zazněla výtka, že teritoriální stát znevýhodňoval př́slušníky národnostních menšin a porušil takto

\footnotetext{
30 Viz např. PRITCHARD, c. d., s. 92-96.

31 Podrobně HILPOLD, Minderheitenschutz im Völkerbundsystem, s. 178.

32 Podrobněji BARTH, W. K. On cultural rights: the equality of nations and the minority legal tradition. Leiden: Martinus Nijhoff, 2008, s. 64-65.

33 Minority Schools in Albania, PCIJ, Advisory Opinion (1935), Series A/B No. 64.

34 Treatment of Polish Nationals and Other Persons of Polish Origin or Speech in Danzig Territory, PCIJ, Advisory Opinion (1932), Series E No. 8.

35 Questions Relating to Settlers of German Origin in Poland (German Settlers in Poland), PCIJ, Advisory Opinion (1923), Series B No. 6.
} 
mezinárodním právem stanovený zákaz diskriminace. Nacistická vláda Německa v roce 1933 informovala Stálý dvůr, že nebude v řízení pokračovat. ${ }^{36}$

Catherine Brölmann, internacionalistka z univerzity v Amsterodamu, se domnívá, že účast mateřských států v systému na ochranu národnostních menšin byla součástí versailleské koncepce rovnováhy. ${ }^{37}$ Proti této tezi ovšem hovoří nízký počet př́ípadů, který se před Stálý dvůr vůbec dostal. Pravda ovšem je, že koncepce ochrany národnostních menšin po druhé světové válce prakticky nikdy nepočítala se žalobami mateřské země proti teritoriálnímu státu. ${ }^{38}$ Přes veškerá omezení byla tedy praxe Stálého dvora mezinárodní spravedlnosti vůči mateřským státům vstřícnější než současný systém.

Větší důraz na roli mateřské země a její spojení s př́ibuznou menšinou v jiném státě však má za následek, že role menšin bez mateřské země je slabší. Bez prŕíslušné podpory se mohla tedy ocitnout rusínská menšina v Československu. Za výjimečné je považováno postavení židovských menšin, které sice nebyly zastoupeny mateřskou zemí, ale měly možnost vyvinout značný politický tlak skrze mezinárodní nevládní organizace a lobbystické skupiny. ${ }^{39}$ To však platilo pouze do doby nástupu nacismu. Do roviny judiciálních řizení před Soudním dvorem se tato politická výhoda ani předtím nepromítala.

\section{Role mateřských států v rámci systému Společnosti národů}

Podle kritických hlasů v odborné literatuře systém Společnosti národů na ochranu národnostních menšin v sobě skrýval potenciál zneužití ze strany mateřských států. Vnitrostátní konflikt mezi národnostní menšinou a teritoriálním státem se mohl lehce přeměnit v mezinárodní konflikt mezi teritoriálním státem a mateřským státem. $Z$ dnešní perspektivy jsou tehdejší konflikty chápány dokonce jako „,katalyzátor pro druhou světovou válku“. ${ }^{40}$

Systém Společnosti národů nemohl ani zabránit některým násilným útokům na národnostní menšiny, ani zajistit loajalitu př́íslušníků některých menšin vůči státům, jejichž byli občany. ${ }^{41}$ Podpora poskytnutá př́ibuzným menšinám mohla být někdy motivována snahou post-imperiálních států o změnu hranic stanovených v pařížských předměstských smlouvách. Petiční řízení mohlo v tomto kontextu sloužit jako nástroj na diskreditaci a delegitimaci nově nezávislých států ve střední a východní Evropě. ${ }^{42} \mathrm{Z}$ této poněkud úzké perspektivy se proto může meziválečná ochrana národnostních menšin jevit jako

36 Polish Agrarian Reform and the German Minority (Interim Measures of Protection), PCIJ, Order of 29 July 1933, Series A/B, No. 58.

37 BRÖLMANN, C. The Permanent Court of International Justice and the International Rights of Groups and Individuals. Amsterdam Law School Legal Studies Research Paper, No. 2012-92, s. 2-3. (Článek je dostupný na https://pure.uva.nl/ws/files/1798268/133053_SSRN_id2151838_1_.pdf).

38 Výjimku představuje žaloba Gruzie proti Rusku z roku 2011. Mezinárodní soudní dvůr v tomto případě dospěl k závěru, že nemá jurisdikci. Viz Case Concerning Application of the International Convention on the Elimination of All Forms of Racial Discrimination (Georgia v Russian Federation), Preliminary Objection, Judgment of 1 April 2012.

39 MALlOY, T. H. Minority Issues in Europe: Rights, Concepts, Policy. Berlin: Frank \& Timme, 2013, s. 44-45.

40 JACKSON-PREECE, J. Diversity and co-existence in international society: the Bolzano/Bozen recommendations in historical perspective. In: PALERMO, F. - SABANADZE, N. (eds.). National Minorities and Inter-State Relations. Leiden: Brill, 2011, s. 29-43, 41.

41 GARDINER JONES, c. d., s. 623.

42 JACKSON-PREECE, J. National minorities and the European nation-states system. Oxford, 2006, s. 84. 
bojiště mezi mateřskými státy národnostních menšin, které usilovaly o revizi hranic, a teritoriálními státy, které měly zájem na tom, zachovat status quo. ${ }^{43}$

Zdá se ovšem, že konečné ztroskotání systému Společnosti národů na ochranu národnostních menšin bylo výsledkem složitějšího procesu. Co se týká iniciativ v rámci orgánů Společnosti národů, byla řada mateřských států původně spíše zdrženlivá. Většina mateřských států byla totiž sama vázána mezinárodními normami o ochraně národnostních menšin. Německo, které představuje zvláštní případ, se do systému zapojilo aktivně až po svém vstupu do Společnosti národů v roce 1926. Tehdy začalo Německo aktivně vyuŽívat nástrojů organizace ve prospěch ochrany německých menšin v Evropě. ${ }^{44}$

Podle Hilpolda je špatné hodnocení meziválečného systému ochrany národnostních menšin založeno na nepochopení role Německa. Hilpold vyzdvihuje pozitivní roli výmarského Německa pod vládou Gustava Stresemanna. Jako čerstvý člen Společnosti národů přistupovalo Německo k samotné myšlence ochrany národnostních menšin konstruktivně a dokázalo i za nepříznivých okolností přesvědčit další členy Rady o nutnosti koncepčních změn. Podle Hilpolda je chybné nerozlišovat mezi vcelku pozitivní rolí Německa do roku 1933 a jeho jednáním po převzetí moci ze strany nacistů. ${ }^{45}$

Pokud se díváme na fungování jednotlivých diplomatických mechanismů, je zřejmé, že pravidla petičního řízení nepřála ani samotným národnostním menšinám, ani mateřským státům. Z určitých obav z budoucí role Německa po vstupu do Společnosti národů Rada ještě v roce 1925, tzn. rok před přijetím Německa do organizace, rozhodla o tom, že v menšinových výborech nemá být zastoupen ani stát, proti němuž petice míŕí, ani jeho sousedský stát, ani mateřský stát autora petice. ${ }^{46}$ Nové pravidlo bylo přijato přes protesty Německa, které namítlo nap̌r. to, že ani francouzský zástupce v menšinovém výboru nevystupuje zcela objektivně v záležitostech týkajících se spřáteleného Polska. Podle Německa měly mateřské státy jako přímo zainteresované státy lepší informace o faktické situaci dotčené menšiny. ${ }^{47}$ Argumenty Německa nakonec nebyly vyslyšeny. ${ }^{48}$

Zatímco mezi tříčlennými výbory a teritoriálními státy probíhala zpravidla intenzivní komunikace a členové menšinových výborů do velké míry vycházeli z informací o př́ípadu, které jim teritoriální stát postoupil, neměl mateřský stát možnost v petičním řízení formálně zaujmout stanovisko. Tuto skutečnost lze dokumentovat na př́kladu Československa, které bylo na základě menšinové smlouvy z roku 1919 plně zapojeno do systému Společnosti národů na ochranu národnostních menšin.

Zástupci německé menšiny v Československu se opakovaně obrátili se svými peticemi na př́islušné orgány Společnosti národů. Jejich námitky týkající se procesu přijímání československé ústavy a postavení německého jazyka ve styku s veřejnými orgány byly sekretariátem Společnosti národů posuzovány jako nerelevantní z pohledu mezinárodních

43 Tamtéž, s. 91.

44 SMEJKAL, T. Protection in Practice: The Minorities Section of the League of Nations Secretariat, 1919-1934. Columbia University, 2010 (práce je dostupná na stránkách https://core.ac.uk/display /27287287).

45 HILPOLD, The League of Nations and the Protection of Minorities, s. 87-124.

46 Podrobněji GÜTERMANN, c. d., s. 194-195.

47 SCHEUERMANN, c. d., s. 35-36.

48 K důvodům aktivnějšího zapojení Německa do mechanismů Společnosti národů viz PETRÁŠ, R. Tradice mezinárodněprávní ochrany menšin a iniciativy „mateřských států“ menšin. Acta Universitatis Carolinae Iuridica, 2015, roč. 61, č. 4, s. 149-159, 157. 
závazků. Za formálně přijatelné byly naopak považovány petice kritizující konkrétní podobu pozemkové reformy a údajné znevýhodňování příslušníků německé menšiny. Ve své odpovědi na petice př́slušníků německé menšiny československá vláda mimo jiné namítla, že opatření související s pozemkovou reformou nespadala pod menšinovou smlouvu, jelikož se mělo jednat o opatření týkající se všech občanů bez ohledu na jejich národnost či občanství. Skutečnost, že reformou bylo dotčeno více vlastníků pozemků, kteří měli německou národnost, souvisela podle československé vlády s vývojem po roce 1620 a historickým bezprávím páchaným na české šlechtě. Začátkem roku 1923 tř̌́členný menšinový výbor z velké části přijal československou argumentaci. Také při zkoumání pozdějších petic, které na problém upozornily, byl tříčlenný výbor odkázán především na oficiální informace poskytnuté československou vládou. Menšinový výbor totiž sám neměl kapacitu a zřejmě ani pravomoci, aby konkrétní výtky přezkoumal. 49

Výhoda teritoriálního státu se ukazovala také např. v souvislosti s pravidelnými návštěvami odborníků menšinové sekce Společnosti národů v zemích, které byly zavázány ustanoveními o ochraně národnostních menšin. Když Pablo de Azcarate y Florez, ještě ve svém postavení jako pracovník menšinové sekce, ${ }^{50}$ jel do oblasti Podkarpatské Rusi, aby zkoumal provádění menšinovou smlouvou upravené územní autonomie ve prospěch rusínské menšiny, byl doprovázen pouze zástupci československé správy. Azcarate výslovně odmítl se setkat se zástupci místních menšinových organizací. ${ }^{51}$ Norský diplomat Erik Andreas Colban, který dlouhou dobu řídil menšinovou sekci Společnosti národů a podnikl řadu oficiálních cest do států vázaných menšinovými smlouvami, později vysvětlil, že se během těchto návštěv snažil chovat jako zástupce veřejné správy teritoriálního státu, protože $\mathrm{z}$ této pozice mohl dotčenou vládu lépe přimět ke kompromisům. ${ }^{52}$

Miklós Zeidler, který se kontaktům mezi menšinovou sekcí Společnosti národů a zástupci územních států věnoval podrobně, psal o skutečně přátelských vztazích např. mezi Colbanem a českým ministrem zahraničních věcí Edvardem Benešem. Beneš se těšil velkému respektu v Ženevě. Za nadstandardní lze považovat také vztahy mezi Colbanem a českým velvyslancem při Společnosti národů Robertem Fiedlerem. Podle Zeidlera nikdy nepanovaly srovnatelně dobré vztahy mezi zástupci Společnosti národů a mad'arskými politiky. ${ }^{53}$

Vzhledem k tomu, že hlavním cílem Společnosti národů bylo udržování světového míru, je pochopitelné, že zástupci organizace byli poměrně rezervovaní vůči politice mateřských států, o kterých se mohli oprávněně domnívat, že budou po roce 1919 usilovat o revizi výsledků Pařížské mírové konference. Na jedné straně byl mechanismus petičního řízení založen s cílem zlepšit postavení národnostních menšin v systému Společnosti národů. Na straně druhé však neměl tento mechanismus být zneužit pro účely posilování role mateřských států. Intenzivní kontakty zástupců Společnosti národů s politiky v územních státech jednoznačně podporovaly pozici těchto států v rámci systému.

49 Podrobně k jednání tř̌́členného výboru o československé pozemkové reformě viz SCHEUERMANN, $c . d$., s. 152-164.

50 Pablo de Azcarate y Flores pracoval pro sekretariát Společnosti národů od roku 1922. Po odchodu norského diplomata Erika Colbana převzal post ředitele menšinové sekce.

51 SCHEUERMANN, c. d., s. 186.

52 Citováno podle SCHEUERMANN, c. d., s. 396.

53 ZEIDLER, M. The League of Nations and Hungarian Minority Protection. In: EILER, F. et alii (eds.). Czech and Hungarian Minority Policy in Central Europe 1918-1938. Prague: Masarykův ústav a Archiv AV ČR, v. v. i., 2009, s. 85-116, 100. 


\section{Závěry}

V tomto př́spěvku jsme se věnovali systému Společnosti národů na ochranu národnostních menšin. Poté, co jsme stručně představili materiální základ ochrany v menšinových smlouvách, menšinových deklaracích a mírových smlouvách uzavřených po první světové válce, zaměřili jsme se na právní úpravu kontrolních mechanismů. Zatímco tři základní nástroje zakotvené prímo v menšinových smlouvách byly v praxi Společnosti národů a jejích orgánů využívány poměrně zřídka, petiční řízení, které nebylo formálně zakotveno, se stalo hlavním kontrolním mechanismem.

S řadou dalších autorů považujeme systém Společnosti národů na ochranu národnostních menšin za velmi zajímavý experiment, který do mezinárodního práva zavedl nové prvky a novou dimenzi. Důležitým prvkem je zapojení jednotlivce do mezinárodních kontrolních procedur. Ačkoli se jednalo o právně nezávazný nástroj a faktická pozice stěžovatelů, resp. autorů petice byla do velké míry závislá na neformálních informacích poskytnutých mateřskými státy nebo sekretariátem Společnosti národů, naznačily pozdější reformy petičního řízení značný potenciál, který tkví v zapojení jednotlivce. Tuto, byt' zcela okrajovou, právní subjektivitu jednotlivce lze považovat za novou dimenzi v systému mezinárodního práva. Společnost národů takto částečně předjímala vývoj, který získal novou dynamiku po druhé světové válce a vedl ke vzniku a postupné stabilizaci ochrany lidských práv jako důležité součásti mezinárodního práva. $V$ tomto vývoji spočívá důležité dědictví Společnosti národů.

$\mathrm{V}$ tomto př́spěvku jsme dále věnovali zvláštní pozornost roli mateřských států, které mohly využívat různých mechanismů Společnosti národů k prosazování ochrany svých př́ibuzných menšin $\mathrm{v}$ zahraničí. Zjistili jsme, že jednací prostor mateřských státu byl větší v neformálních jednáních než ve formálním řízení před orgány Společnosti národů. $Z$ důvodů, které jsou zčásti jistě pochopitelné, usilovala řada členských států a také zástupci Společnosti národů o minimalizaci vlivu mateřských států. Praxe Společnosti národů však také ukázala, že nelze ze systému mezinárodního práva úplně vymýtit aspekt etnických, náboženských a kulturních vazeb mezi př́slušníky určité etnické či náboženské skupiny. Jak ukazuje emotivní debata o současných aktivitách mateřských států v Evropě, má tento problém nadále svoji relevanci. ${ }^{54}$

Co se týče ztroskotání meziválečné koncepce ochrany národnostních menšin v 30 . letech minulého století, nelze ochranu národnostních menšin oddělit od konkrétního kontextu, ve kterém Společnost působila. Úspěšnost různých mechanismů na ochranu národnostních menšin byla do velké míry závislá na úspěších Společnosti národů jako takové, a to zejména v oblasti udržování světového míru. Bylo by zrejmě naivní očekávat, že samotná ochrana národnostních menšin a její zakotvení v mezinárodních dokumentech dokáže zabránit agresivnímu postupu nedemokratických států. I v tomto směru lze ze zkušeností Společnosti národů odvodit důležité poselství. Mezinárodní ochrana národnostních menšin i mezinárodní ochrana lidských práv mohou fungovat pouze $\mathrm{v}$ prostředí stability a bezpečí a pouze dokud právní vědomí převažuje nad krátkodobými politickými zájmy států.

54 Podrobněji SCHEU, H. C. Postavení „mateřské země“ a příbuzné menšiny z hlediska mezinárodní ochrany lidských práv. Acta Universitatis Carolinae Iuridica, 2015, roč. 61, č. 4, s. 169-182. 